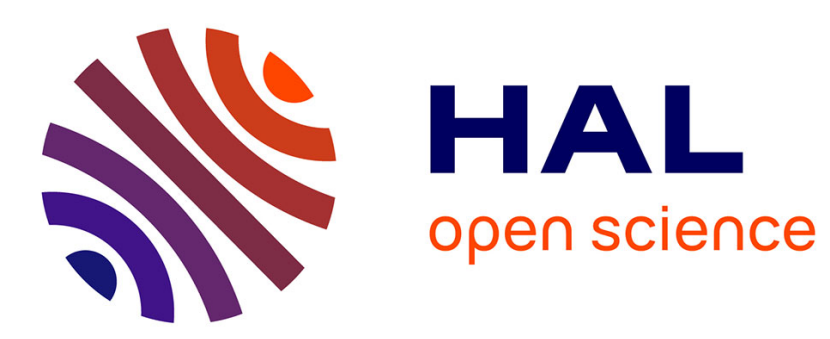

\title{
Texture of Parmigiano Reggiano cheese: Statistical relationships between rheological and sensory variates
}

\author{
Y Noël, M Zannoni, Ea Hunter
}

\section{To cite this version:}

Y Noël, M Zannoni, Ea Hunter. Texture of Parmigiano Reggiano cheese: Statistical relationships between rheological and sensory variates. Le Lait, 1996, 76 (3), pp.243-254. hal-00929483

\section{HAL Id: hal-00929483 \\ https://hal.science/hal-00929483}

Submitted on 1 Jan 1996

HAL is a multi-disciplinary open access archive for the deposit and dissemination of scientific research documents, whether they are published or not. The documents may come from teaching and research institutions in France or abroad, or from public or private research centers.
L'archive ouverte pluridisciplinaire HAL, est destinée au dépôt et à la diffusion de documents scientifiques de niveau recherche, publiés ou non, émanant des établissements d'enseignement et de recherche français ou étrangers, des laboratoires publics ou privés. 


\title{
Texture of Parmigiano Reggiano cheese: Statistical relationships between rheological and sensory variates
}

\author{
Y Noël'1, M Zannoni², EA Hunter ${ }^{3}$ \\ ${ }^{1}$ Station de recherches en technologie et analyses laitières, Inra, BP 89, 39801 Poligny cedex, \\ France; ${ }^{2}$ Consorzio del Formaggio 'Parmigiano Reggiano', Via JF Kennedy, 18, 42100 Reggio \\ Emilia, Italy; ${ }^{3}$ Biomathematics and Statistics Scotland, BioSS, The University of Edinburgh, \\ Edinburgh, EH9 3JZ, UK
}

(Received 6 April 1995; accepted 16 October 1995)

\begin{abstract}
Summary - The texture of Parmigiano Reggiano cheese was studied by rheological and sensory analysis. Twelve cheeses, four samples of three ages (12, 18 and 28 months), were selected at random from 12 dairies. Four rheological parameters can describe the differences between the cheeses: apparent elastic modulus and stress, strain and work at fracture. Sensory analysis followed a procedure recently established within the EC Flair programme in which textural attributes were evaluated using a seven-point scale. A large and statistically 'highly significant' effect of age was found on the elastic modulus and the strain at fracture, and a smaller and less significant effect on many of the sensory attributes. A large effect of age was also shown on the presence of crystals, a typical characteristic of mature Parmigiano Reggiano cheese. Six of the sensory variates were found to be predicted by rheological variates using partial least squares regression. This was a preliminary study on the prediction of sensory quality from rheological data which will need further evaluation of a great number of samples to obtain conclusive results to be used for practical purpose.
\end{abstract}

texture / rheology / sensory analysis / relationship study / Parmigiano Reggiano cheese

Résumé - Texture du Parmigiano Reggiano : relations statistiques entre les paramètres rhéologiques et sensoriels. Les propriétés texturales du fromage de Parmigiano Reggiano sont examinées par analyses rhéologique et sensorielle. Les analyses portent sur 12 fromages de trois âges différents (12, 18, 28 mois) sélectionnés dans 12 fromageries choisies au hasard. Le comportement rhéologique des fromages est décrit de façon satisfaisante par quatre paramètres : le module élastique apparent, la contrainte, la déformation et l'énergie à la fracture. L'analyse sensorielle mise en œuvre suit une procédure récemment développée dans le cadre d'un programme européen Flair, et évalue huit paramètres sensoriels sur une échelle à sept points. Un effet important, et statistiquement significatif, de l'âge est mis en évidence sur le module élastique et la déformation à la fracture, et un effet plus faible et moins significatif de l'âge sur la plupart des caractéristiques sensorielles. Un effet important de l'âge est aussi mis en évidence sur la présence de cristaux, caractéristique spécifique du Parmigiano Reggiano affiné longtemps. Une bonne prédiction de six paramètres texturaux à partir des paramètres rhéologiques est mise en évidence par une méthode statistique de régression multi- 
dimensionnelle (PLS). Cette étude préliminaire sur la prédiction de la qualité sensorielle des fromages à partir des données rhéologiques nécessitera d'autres évaluations sur un plus grand nombre d'échantillons pour obtenir des résultats utilisables en pratique.

texture / rhéologie / analyse sensorielle / étude relationnelle / Parmigiano Reggiano fromage

\section{INTRODUCTION}

Texture studies on cheese, especially hard and semi-hard cheese, have been carried out for many years (Walstra and Van Vliet, 1982). The results are of great importance for those involved in the chain of production, from farmer to consumer (Walstra and Peleg, 1991). There is great interest in defining quality, especially for 'Appellation d'Origine Contrôlée' (AOC) cheeses (Grappin et al, 1993). Production of consistently high quality $\mathrm{AOC}$ cheeses continues to be a great challenge. There is a need to increase knowledge on the mechanisms governing the quality of the final product to develop production processes yielding consistent results.

Because texture is a multivariate attribute, studies encounter many difficulties. Sensory and instrumental methods are not standardized. Relationships between sensory and instrumental measurements are poorly defined (Walstra and Peleg, 1991) despite their importance (Szczesniak, 1987).

Appropriate statistical tools for relational studies are not widely used, because they are not always fully understood by sensory and rheological scientists. In particular, the use of multivariate analysis methods, such as principal component analysis, biplots, principal component regression and partial least squares regression are not generally familiar to researchers. Williams et al (1988) and Brockhoff et al (1993) discuss appropriate statistical methods in the context of food science.

Recently several relational studies have been published, mainly between sensory and chemical variates (Molander et al, 1990; Bosset et al, 1992, 1993a, b; Virgili et al, 1994) or between chemical and rheological variates (Rohm et al, 1992a, b). Several studies have been published about relationships between rheology and sensory properties (Marshall, 1991; Hennequin and Hardy, 1993; Jack et al, 1993), as well as a brief critical review by Zoon (1991). This paper reports on such a study on Parmigiano Reggiano cheese.

Parmigiano Reggiano is an $A O C$ hard cheese, produced in the north of Italy, in an area limited to the provinces of Parma, Reggio Emilia, Modena and parts of Bologna and Mantua. It is made from raw milk, partially skimmed, added with whey starters and then coagulated with rennet. The renneting time is about $12 \mathrm{~min}$ : the curd is then cut to finally obtain granules of the size of rice grains. It is heated to $55^{\circ} \mathrm{C}$ (about $13 \mathrm{~min}$ after renneting) then heating and stirring stop the curd grains settle. After $45 \mathrm{~min}$, the curd is removed, put in moulds and lightly pressed. After 3 weeks of salting in brine the Parmigiano Reggiano cheese is normally ripened for 2 years. The weight of a ripened cheese is on average $37 \mathrm{~kg}$, its shape is like a barrel. The diameter is about $44 \mathrm{~cm}$ and the height about 24 $\mathrm{cm}$. The average composition of a 2-yearold Parmigiano Reggiano cheese is: dry matter $69 \%$, protein $33 \%$, fat $28 \%, \mathrm{NaCl}$ $1.4 \%$ and the soluble $\mathrm{N} /$ total $\mathrm{N}$ ratio is $34 \%$,

The cheese has a distinctive texture - a hard consistency, granular structure and the presence of crystals of tyrosine. Until now, scientific information about rheological and sensory characteristics and their relationship has been lacking.

Rheological measurements are related to mechanical attributes of texture. Sensory 
analysis evaluates not only mechanical characteristics of texture but also geometrical (related to size, shape and arrangement of particles) and surface ones (related to sensations produced by moisture and/or fat content) (AFNOR, 1992). This relational study considers all the sensory attributes of texture even though geometrical and surface criteria cannot be evaluated directly by rheological measurements. The relationships between rheological and sensory parameters are discussed.

\section{MATERIALS AND METHODS}

\section{Cheese samples}

Parmigiano Reggiano cheese, according to the Italian law, is ripened for at least 12 months but is normally marketed at 24 months. For this study cheeses of 12,18 and 28 months of age were selected for testing. For each of the three ages, four cheeses were selected at random from different dairies, which were also chosen at random. Any cheese effect may thus be due to differences in the milk used and to differences in cheese making conditions. The cheese wheels were cut and two 2-kg samples were taken: one for sensory and the other for rheological testing.

\section{Rheological analysis}

Samples of cheese were stored overnight at the test temperature $\left(18^{\circ} \mathrm{C} \pm 0.5^{\circ} \mathrm{C}\right)$. Sub-samples were taken midway between centre and rind, with a cork-borer mounted on a drilling machine stand, driven slowly by hand. The cork-borer was lightly lubricated with paraffin oil. The cylinders (diameter $20 \mathrm{~mm}$ ) were cut with a stretched-wire cutting device to a height of $20 \mathrm{~mm}$. These test pieces were stored in a small airtight box (to avoid dehydration), for $1 \mathrm{~h}$, to allow complete relaxation before testing.

The rheological method used was the uniaxial compression at constant displacement rate, whose standardization was studied by an IDF group of experts (Anonymous, 1990). A 'Rheometre Digital Inra'(Cardenas-Caroti et al, 1985), equipped with parallel plates (stainless steel, diameter $=50 \mathrm{~mm}$ ) and a $500 \mathrm{~N}$ load cell, was used. Data on force and displacement were fed into a personal computer, at a rate of six measurements per second. The displacement rate was $50 \mathrm{~mm} / \mathrm{min}$, giving an initial strain rate of approximately $4.210^{-2} \mathrm{~s}^{-1}$. Four specimens were tested from each sample.

After smoothing the results by a 'moving average' software module, force and displacement values were transferred into a spreadsheet programme for further analysis. The first step was to convert the raw data into stress and strain.

Parmigiano Reggiano cheese fractures at relatively low strain (approximately 0.20 ), implying that the results could be analysed, with a quite good approximation, on the basis of Cauchy strain (Reiner, 1971; van Vliet and Peleg, 1991), and uncorrected stress. This means that stress is calculated as the ratio of measured force to initial surface area of the test piece instead of surface area calculated on the assumption that the sample deforms as a cylinder (Luyten et al, 1991).

Figure 1 shows an example of a stress-strain curve, and the different parameters evaluated. The apparent elastic modulus $\mathrm{E}$ (unit $\mathrm{kPa}$ ) was calculated by estimation of the slope of the linear part of the stress-strain curve. This parameter gives information about the elasticity of the cheese, ie, the resistance of the cheese structure to reversible deformation, without fracturing.

The stress, $\sigma_{L E}$ (unit: $\mathrm{kPa}$ ), and strain, $\varepsilon_{L E}$ (no dimension), at the apparent linear limit were also determined. The maximum of the stress-strain curve was considered to be the fracture point (Luyten, 1988); the stress at fracture, $\sigma_{f}$ (unit: $\mathrm{kPa}$ ), was estimated as the maximum stress of the stress-strain curve, and the strain, $\varepsilon_{f}$ at fracture (no dimension) as the corresponding strain. The ratio between the stress and the strain at fracture, which is a kind of modulus, $M_{f}$ (unit: $\mathrm{kPa}$ ), is also considered. Finally, the work to deform the sample until the apparent linear limit, $W_{L}$ and the work at fracture, $W_{1}$, were also evaluated by the area under the stress-strain curve (unit: $\mathrm{kJ} / \mathrm{m}^{3}$ )

\section{Sensory analysis}

The sensory analysis of texture followed the procedure described recently by Lavanchy et al (1993), resulting from a collaborative study on hard and semi-hard cheeses between several European countries within the EC FLAIR programme. Scales from 1 to 7 are used for elasticity, firmness, deformability, brittleness, adhesivity, humidity, solubility, while granularity is 


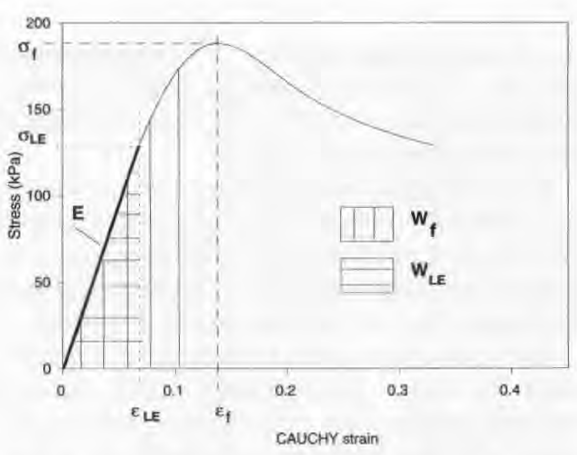

Fig 1. Example of a stress-strain curve. E, elastic modulus; $\sigma_{\mathrm{LE}}$ and $\varepsilon_{\mathrm{LE}}$, stress and strain at the linear limit; $\sigma_{\mathrm{f}}$ and $\varepsilon_{i}$, stress and strain at fracture; $W_{L E}$ and $W_{1}$, work to the linear limit and work to fracture.

Exemple de courbe contrainte - déformation $E$, module élastique apparent; $\sigma_{L E}$ et $\varepsilon_{L E}$, contrainte et déformation à la limite de linéarité; $\sigma_{f}$ et $\varepsilon_{\text {, }}$, contrainte et déformation à la fracture; $W_{L E}$ et $W_{t}$, travail jusqu'à la limite de linéarité et travail jusqu'à la fracture.

sub-divided into four characteristics (fine, floury, grainy and coarse), each one with a three-level scale (low, medium, high). These serisory attributes were described in detail by Lavanchy et al (1993). For the purpose of this study only floury and grainy were used. In previous tests, 'fine' was never observed, while 'coarse' was only rarely observed and with such poor repeatability that it was not considered in this study. The presence of crystals was also evaluated on a three-level scale. Elasticity was the only sensory attribute evaluated by touch.

The 12 Parmigiano Reggiano cheese samples were divided into three sub-groups of the same age (ie, 28, 18 and 12 months) for sensory testing by a group of $8-10$ trained panellists. The sub-groups were tested in separate sessions. The samples were cut into small pieces of $1.5 \times$ $2 \times 7 \mathrm{~cm}$ prior to testing.

\section{Statistical methods}

The following methods were used to analyze the rheological and sensory data: analysis of variance, principal component analysis, biplots. The relational analysis was carried out using partial least squares regression (Martens and Martens, 1986). All calculations were carried out using the
Genstat 5 statistical package (Copyright 1992 , Lawes Agricultural Trust, Rothamsted Experimental Station, Harpenden, Herts, UK).

\section{RESULTS AND DISCUSSION}

\section{Univariate analysis}

The rheological and sensory data were first analysed by analysis of variance. For the rheological data, measurements from four sub-samples from each sample were available. It was thus possible to derive a subsampling error for each variate. This source of variation includes the lack of homogeneity in the samples of each cheese and the variability of the measurement technique. For the sensory data, means over judges and standard deviations of the distributions were available. An estimate of the sampling variance was calculated from the standard deviations- this estimate will be biased upwardly because each judge consistently used a different part of the scale to differentiate between samples. Variance ratio tests (F-tests) - see column vr (1) in tables I and II - were used to assess the effects of age and $t$-tests to interpret the tables of means. The variance ratio test of the between cheeses (within age) against the sampling error, see column vr (2), provides evidence of the extent of variability between cheeses.

\section{Rheological data}

The results of the analysis of variance are given in table 1.

The rheological parameters, which are highly significant $(P<0.01)$, are related to the response of the samples at small deformations: the elastic modulus, the stress and the work at the end of the linear part of the stress-strain curve. The older the cheese, the higher the elastic modulus. The value of the elastic modulus rises by a factor of 1.7 between 12 and 28 months, which indicates a considerable decrease in the elasticity of the 
Table I. Rheological parameters: means, standard error of differences (sed), variance ratios (vr) and probabilities.

Paramètres rhéologiques - moyennes, erreurs standard des différences, variances (vr) et probabilités.

\begin{tabular}{|c|c|c|c|c|c|c|c|}
\hline & \multicolumn{3}{|c|}{ Age (months) } & \multirow[t]{2}{*}{ sed } & \multirow[t]{2}{*}{$v r^{1}$} & \multirow[t]{2}{*}{ prob $v r^{2}$} & \multirow[t]{2}{*}{ prob } \\
\hline & 12 & 18 & 28 & & & & \\
\hline Modulus $\mathrm{E}[\mathrm{kPa}]$ & 1340 & 1530 & 2280 & 190 & 13.80 & ${ }^{* *} 6.48$ & $* * *$ \\
\hline \multicolumn{8}{|l|}{ At linear limit } \\
\hline Stress $\sigma \mathrm{LE}[\mathrm{kPa}]$ & 117.3 & 130.4 & 190.9 & 14.96 & 13.80 & ** 5.77 & $* * *$ \\
\hline Strain ELE $[-]$ & 0.0786 & 0.0758 & 0.0752 & 0.00144 & 3.21 & ns 2.32 & \pm \\
\hline Work WLE $\left[\mathrm{kJ} / \mathrm{m}^{3}\right]$ & 5.36 & 5.78 & 8.33 & 0.622 & 13.40 & ** 4.48 & *** \\
\hline \multicolumn{8}{|l|}{ At fracture } \\
\hline Stress of $[\mathrm{kPa}]$ & 211 & 199 & 186 & 33.8 & 0.27 & ns 9.36 & $* \star \star$ \\
\hline Strain $\varepsilon_{f}[-]$ & 0.219 & 0.178 & 0.121 & 0.0278 & 6.22 & ${ }^{*} 28.48$ & $\star \star \star$ \\
\hline Modulus $\mathrm{M}_{\mathrm{f}}[\mathrm{kPa}]$ & 1001 & 1151 & 1528 & 266.3 & 2.08 & nst 0.05 & $* * *$ \\
\hline Work $W_{f}\left[\mathrm{~kJ} / \mathrm{m}^{3}\right]$ & 30.6 & 23.8 & 18.4 & 5.13 & 2.83 & $\mathrm{~ns} 19.50$ & $* * \star$ \\
\hline
\end{tabular}

\footnotetext{
${ }^{\top}$ Variance ratio test of age mean square against between cheeses (within age) mean square, 2 and 9 degrees of freedom.

Valeur de F : rapport de la somme des carrés des écarts dus à lâge sur la somme des carrés des écarts dus au fromage pour un âge donné, deux et neuf degrés de liberté.

${ }^{2}$ Variance ratio test between cheeses (within age) mean square against sampling mean square with 9 and (approximately) 36 degrees of freedom.

Valeur de F : rapport de la somme des carrés des écarts dus au fromage pour un âge donné sur la somme des carrés des écarts résiduels, 9 et (approximativement) 36 degrés de liberté $n s \sim P>0.05 ;{ }^{*} \sim 0.05>P>0.01 ; * * 0.01>P>0.001 ; * * * 0.001>P$.
}

cheese, or alternatively an increase in the 'rigidity'. The older the cheese the lower the water content (Zannoni et al, 1991) - the mean values for the dry matter for the three ages were $63.30,66.15$ and $68.87 \mathrm{~g}$ per $100 \mathrm{~g}$ of cheese, with standard deviations of $0.59,0.69$ and 0.61 respectively. The role of water on the elasticity of the cheeses is suspected: water can act as a 'lubricant' between the molecules, especially the caseins, thus elastic deformation of the protein matrix is easier when the water content is higher, which is the case with younger Parmigiano Reggiano. The relation between water and elasticity has been observed by Chen et al (1979) in different cheese varieties, also mentioned by Rüegg (1985), and especially studied by Luyten (1988).

The strain at fracture decreases significantly $(P<0.05)$ with age, this means that the cheese becomes more brittle. During the long ripening of Parmigiano Reggiano, the protein matrix of the cheese is broken down by proteolysis, as shown by the high values of soluble nitrogen in ripened cheese (Bütikofer et al, 1993); the weakness of the structure due to this phenomenon would induce a decrease in the fracture strain with age. Moreover, the difference between the strain at the linear limit and the fracture strain decreases with age. This could mean that age affects the structure in such a way that cracks within the cheese body progress faster in older cheeses than in younger cheeses. Thus some plastic deformation of younger cheeses, which are less affected by proteolysis and which have a lower dry matter content, is also suspected. Studies are needed to further explore this assumption. 
Table II. Sensory parameters: means, standard error of differences (sed), variance ratios (vr) and probabilities.

Paramètres sensoriels : moyennes, erreurs standard des différences, variances (vr) et probabilités.

\begin{tabular}{|c|c|c|c|c|c|c|c|c|}
\hline & \multicolumn{3}{|c|}{ Age (months) } & \multirow[t]{2}{*}{ sed } & \multirow[t]{2}{*}{$v r^{1}$} & \multirow[t]{2}{*}{ prob } & \multirow[t]{2}{*}{$v r^{2}$} & \multirow[t]{2}{*}{ prob } \\
\hline & 12 & 18 & 28 & & & & & \\
\hline Elasticity & 2.81 & 2.29 & 1.65 & 0.318 & 6.63 & $\star$ & 7.12 & $\star \star \star \star$ \\
\hline Firmness & 4.15 & 4.54 & 5.22 & 0.314 & 5.85 & * & 2.71 & $\star$ \\
\hline Deformability & 3.82 & 3.35 & 2.90 & 0.268 & 5.86 & $\star$ & 2.68 & $\star *$ \\
\hline Brittleness & 3.30 & 4.07 & 3.79 & 0.436 & 1.30 & ns & 5.50 & $\star \star \star \star$ \\
\hline Adhesivity & 3.19 & 3.28 & 3.10 & 0.174 & 0.52 & ns & 1.05 & ns \\
\hline Humidity & 3.14 & 2.94 & 2.64 & 0.185 & 3.84 & ns & 2.14 & ns \\
\hline Solubility & 3.55 & 4.24 & 4.45 & 0.287 & 5.43 & $*$ & 2.44 & $\star$ \\
\hline Floury & 1.26 & 1.95 & 1.09 & 0.284 & 5.10 & * & 2.12 & ns \\
\hline Grainy & 2.33 & 2.97 & 3.84 & 0.518 & 4.27 & * & 2.96 & * \\
\hline Crystals & 1.18 & 1.61 & 2.59 & 0.350 & 8.56 & $\star *$ & 3.48 & $\star \star$ \\
\hline
\end{tabular}

\footnotetext{
${ }^{1}$ Variance ratio test of age mean square against between cheeses (within age) mean square, 2 and 9 degrees of freedom.

Valeur de F : rapport de la somme des carrés des écarts dus à l'âge sur la somme des carrés des écarts dus au fromage pour un âge donné, 2 et 9 degrés de liberté.

${ }^{2}$ Variance ratio test between cheeses (within age) mean square against sampling mean square with 9 and (approximately) 96 degrees of freedom.

Valeur de $F$ : rapport de la somme des carrés des écarts dus au fromage pour un âge donné sur la somme des carrés des écarts résiduels, 9 et (approximativement) 96 degrés de liberté.

$n s \sim P>0.05 ;{ }^{*} \sim 0.05>P>0.01 ; * * 0.01>P>0.001 ; \cdots \sim 0.001>P$.
}

The effect of cheese on the rheological parameters is highly significant independently of age effect.

Presumably, milk composition and cheesemaking conditions are sources of variation for cheese texture, due to the random selection of cheese from dairies. A similar effect has already been mentioned by Berdagué and Grappin (1988) on Comté which is also a hard cheese made from raw milk.

\section{Sensory data}

The results of the analysis of variance are given in table II.

The effect of age is significant, but not highly, on elasticity, firmness, deformability, solubility, floury, and grainy, and highly significant on crystals. It is not significant on brittleness, adhesivity or humidity. Elastici- ty and deformability decrease with age. Firmness and solubility increase with age, as well as the grainy characteristic, and the increase of crystals with age is particularly important between 18 and 28 months. Floury is perceived as slightly more intense at 18 months than at 12 and 28 months. Similar effects of age have been reported previously by Zannoni et al (1991) on firmness, humidity, solubility, granularity, crystals and cohesion.

The effect of cheese is very highly significant only for elasticity and brittleness. Interestingly elasticity, firmness and deformability are influenced by both age and by cheese, while brittleness is only influenced by cheese. This unexpected result for brittleness may be partly explained by the way in which the sensory testing was organized. 


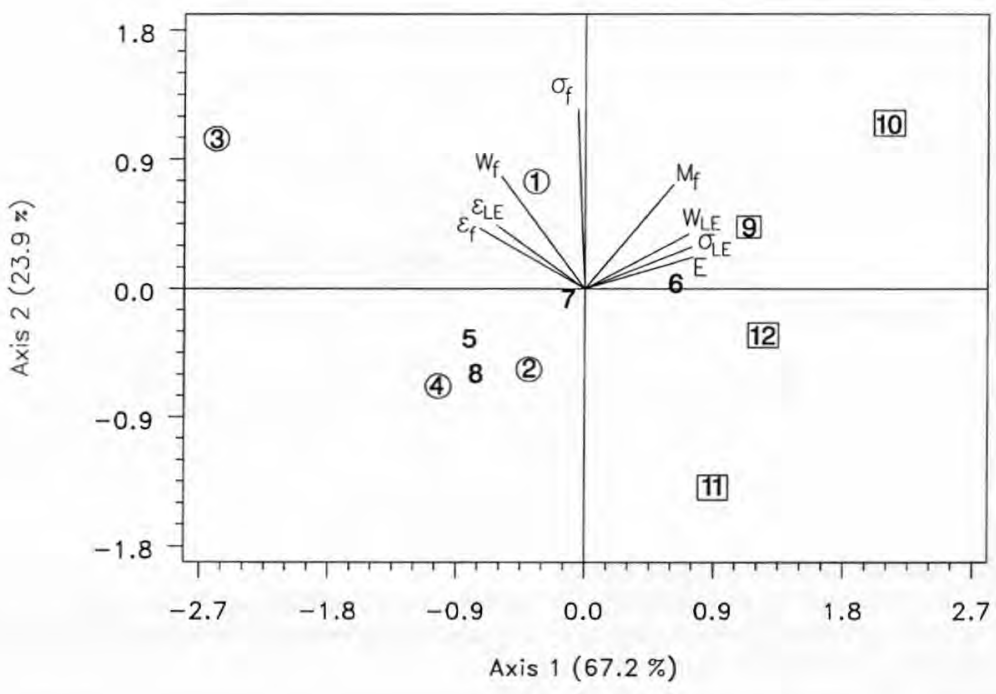

Fig 2. Biplot representation of rheological results. See legend figure 1 for description of the rheological parameters. $M_{\mathrm{t}}$, modulus at fracture. Circled numbers: 12; month-old cheeses; simple numbers: 18 month-old cheeses; squared numbers: 28 ; month-old cheeses.

Représentation de type biplot des résultats rhéologiques. Voir la légende de la figure 1 pour la description des paramètres rhéologiques. $M_{t}$, module à la fracture. Fromages âgés de 12 mois (chiffres entourés d'un cercle), de 18 mois (chiffres simples), de 28 mois (chiffres entourés d'un carré).

By testing samples of the same age in one session, it is easier for the panel to discriminate among cheeses than among ages.

The results show the typical textural features of Parmigiano Reggiano: low elasticity and humidity; high firmness; medium-low deformability and adhesivity; medium brittleness, solubility and granularity. In spite of the training, the panel had problems in evaluating the granularity, confirming the difficulty of testing for this characteristic. The panel had also problems in assessing the adhesivity of different samples; fortunately this attribute is not an important characteristic of Parmigiano Reggiano cheese.

\section{Multivariate analysis}

Tables I and II give the results of the analysis of variance. However, they are voluminous and do not readily lend themselves to a diagrammatic representation. In order to capture the main features of the data, aprincipal component analysis was performed on the two parts of data separately. The results are displayed in the form of principal component biplots (Krzanowski, 1988) for the means of each cheese (figs 2 , 3). In these diagrams numbers refer to the cheeses: 1-4 are 12-month-old cheeses, 5-8 are 18-month-old cheeses and 9-12 are 28-month-old cheeses. Variates that lie in the same orientation from the origin give the same information on the samples and, similarly, samples that lie in the same orientation have a similar pattern of results.

\section{Rheological data}

A principal component analysis of the sample means was performed.

Three components are important. Analysis of variance of the first principal component 


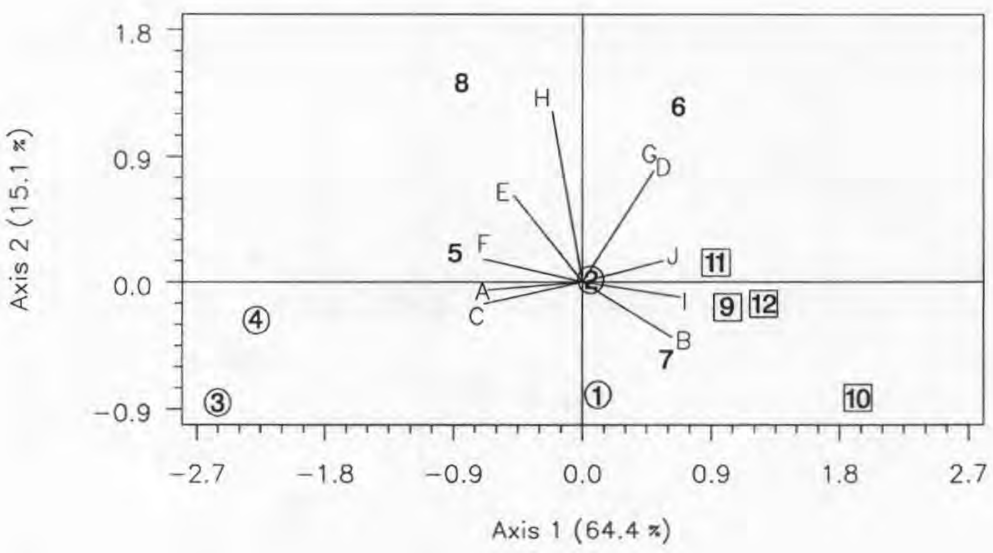

Fig 3. Biplot representation of sensory results.

A, elasticity; B, firmness; C, deformability; D, brittleness; E, adhesivity; F, humidity; G, solubility; $\mathrm{H}$, floury; I, grainy; J, crystals. Circled numbers, 12-month-old cheeses; simple numbers, 18-month-old cheeses; squared numbers, 28-month-old cheeses.

Représentation de type biplot des résultats d'analyse sensorielle. A, élasticité; $B$, fermeté; $C$, déformabilité ; $D$, friabilité ; $E$, adhésivité ; $F$, impression d'humidité ; $G$, solubilité ; $H$, farineux ; $I$, granuleux ; J, crystals. Fromages âgés de 12 mois (chiffres entourés d'un cercle), de 18 mois (chiffres simples), de 28 mois (chiffres entourés d'un carré).

score shows it to be associated with age and the second principal component score with both age and cheese. The third component is error. Consequently, the first two scores summarize the data. The biplot of the cheese by variate table (fig 2) shows intermingling of the 12-month-old and 18month-old samples. However, the 28month-old samples are distinctly different. As expected, elastic modulus, stress and work at the linear limit and modulus at fracture appear to give similar information on these samples. Also strain at the linear limit and strain and work to fracture give similar but different information to the first group. Stress at fracture apparently provides unique information on the samples. While stress and work at fracture vary mainly with cheese, the other variates vary mainly with age. Two cheeses appear to react as extreme cases on the biplot figure, number 3 from 12-month-old samples, and number 10 from 28-month-old samples.

Finally four variates, elastic modulus and stress, strain at fracture and work to frac- ture were selected to represent the full rheological data set. A biplot using only these variates is very similar to figure 2 confirming that these variates capture the rheological information.

\section{Sensory data}

The principal component analysis shows that two components summarize the sensory data. The first is related to age and the second to age and cheese. The biplot of the cheese by variate table (fig 3 ) shows the 28-month-old samples to be different. The 18- and 12-month-old cheeses are in more widely dispersed groups. The variates are well spread out, although elasticity and deformability and also brittleness and solubility provide similar information. The similarity of elasticity and deformability suggests that the panel perceived these characteristics to be very similar for the Parmigiano Reggiano cheese. The close relationship between brittleness and solubility is not so easy to explain. Nevertheless, it is well known that these characteristics both in- 
Table III. Equations to predict sensory from rheology.

Équations de prédiction des paramètres sensoriels par les paramètres rhéologiques.

\begin{tabular}{|c|c|c|c|c|c|c|c|}
\hline \multicolumn{8}{|c|}{ Coefficients } \\
\hline $\begin{array}{l}\text { Sensory } \\
\text { character }\end{array}$ & Constant & $\begin{array}{l}\text { Elastic } \\
\text { modulus }\end{array}$ & $\begin{array}{l}\text { Stress at } \\
\text { fracture }\end{array}$ & $\begin{array}{l}\text { Strain at } \\
\text { fracture }\end{array}$ & $\begin{array}{l}\text { Work to } \\
\text { fracture }\end{array}$ & $N$ & Sep \\
\hline Elasticity & 2.63 & $-6.19 \mathrm{E}^{-4}$ & $-2.21 \mathrm{E}^{-3}$ & $4.37 \mathrm{E}^{-2}$ & $1.50 \mathrm{E}^{-2}$ & 2 & 89.50 .229 \\
\hline Firmness & 3.32 & $-6.62 \mathrm{E}^{-4}$ & $4.32 \mathrm{E}^{-3}$ & $-3.30 \mathrm{E}^{-2}$ & $-4.46 \mathrm{E}^{-3}$ & 2 & 73.10 .336 \\
\hline Deformability & 2.75 & $-3.38 E^{-4}$ & $1.00 \mathrm{E}^{-3}$ & $3.26 \mathrm{E}^{-2}$ & $1.74 \mathrm{E}^{-2}$ & 1 & 81.20 .259 \\
\hline Brittleness & 4.51 & $1.94 \mathrm{E}^{-4}$ & $-9.63 E^{-4}$ & $2.80 \mathrm{E}^{-2}$ & $-1.75 E^{-2}$ & 1 & 37.20 .547 \\
\hline Adhesivity & 3.25 & $-1.23 E^{-4}$ & $-3.73 E^{-4}$ & $8.92 \mathrm{E}^{-3}$ & $3.07 E^{-3}$ & 1 & $\begin{array}{lll}27.0 & 0.217\end{array}$ \\
\hline Humidity & 0.93 & $3.99 \mathrm{E}^{-4}$ & $3.52 \mathrm{E}^{-4}$ & $2.08 \mathrm{E}^{-1}$ & $-9.71 \mathrm{E}^{-2}$ & 4 & 93.30 .097 \\
\hline Solubility & 4.94 & $2.31 \mathrm{E}^{-4}$ & $-1.77 \mathrm{E}^{-3}$ & $-2.76 \mathrm{E}^{-2}$ & $-1.75 \mathrm{E}^{-2}$ & 1 & 57.90 .376 \\
\hline Floury & 1.43 & - & - & - & - & 0 & 0.00 .578 \\
\hline Grainy & 1.17 & $9.69 \mathrm{E}^{-4}$ & $7.99 \mathrm{E}^{-3}$ & $-5.87 E^{-2}$ & $-1.49 E^{-2}$ & 2 & $87.4 \quad 0.362$ \\
\hline Crystals & 0.61 & $8.50 \mathrm{E}^{-4}$ & $3.33 \mathrm{E}^{-3}$ & $-4.16 \mathrm{E}^{-2}$ & $-9.10 E^{-3}$ & 2 & $76.8 \quad 0.392$ \\
\hline
\end{tabular}

${ }^{1}$ Coefficients are given in exponential form. Les coefficients sont exprimés sous forme exponentielle.

${ }^{2} \mathrm{~N}$, number of linear components / nombre de composantes linéaires.

${ }^{3} \mathrm{R}^{2}$, percentage variation accounted for by model fitting / pourcentage de variation expliquée par le modèle prédictif. ${ }^{4} \mathrm{Sep}$ - standard error of prediction / erreur standard de prédiction.

crease during the ripening of Parmigiano Reggiano cheese. High sensory values for the characters firmness, granularity and crystals are typical for the oldest cheeses (28-month-old), while higher values for deformability, elasticity and humidity are connected with the younger cheeses. The attribute crystals increase with age and the samples can be roughly divided into two subgroups: those without crystals (12 months) and those with crystals (28 months) while the 18-month samples were divided between these two groups.

\section{Relational analysis}

The simplest method of relating sensory data to rheological data is by correlation. The matrix of correlations, not given here, contains many high values indicative of statistical relationships. However, there is a large number of paired comparisons and consequently a high probability of finding 'significant' correlations with such a small number of samples. A more cautious strategy is to relate the sensory data to the rheological data using partial least squares (Martens and Martens, 1986). This method finds linear combinations of the rheological variates which predict the sensory variates. The optimum number of linear combinations is determined, for each sensory variate, using cross-validation.

Table III gives the equations derived by PLS regression predicting the sensory variables. Given the four rheological measurements, it is possible to predict the sensory measurements. For example, suppose that for a new cheese we have the following rheological measurements: elastic modulus, 1715; stress at fracture, 252.5; strain at fracture, 20.65; and work to fracture, 34.83 . The value for sensory elasticity for this cheese is predicted to be:

$$
\begin{gathered}
2.63-6.19 \mathrm{E}-4^{*} \text { elastic modulus }-2.21 \mathrm{E}-3^{*} \text { stress at fracture } \\
+4.37 \mathrm{E}-2^{*} \text { strain at fracture }+1.50 \mathrm{E}-2^{*} \text { work to fracture } \\
=2.63-6.19 \mathrm{E}-4^{*} 1715-2.21 \mathrm{E}-3^{*} 252.5 \\
+4.37 \mathrm{E}-2^{*} 20.65+1.50 \mathrm{E}-2 * 34.83 \\
=2.44
\end{gathered}
$$


The column headed $\mathrm{N}$ shows the number of PLS components justified by cross-validation and the column headed $R^{2}$ the percentage of the variation accounted for by the fit of the model to the experimental data. The column headed Sep is the standard error of prediction and gives a measure of the quality of the prediction.

Six sensory variates, elasticity, firmness, deformability, humidity, grainy and crystals, are predicted by the four rheological parameters, with $\mathrm{R}^{2}$ values between $73.1 \%$ and $93.3 \%$. Three sensory variates, brittleness, adhesivity and solubility, are poorly predicted. Floury is not related to any of the rheological parameters (see table III).

Our prior expectation was that elasticity, firmness and deformability will be predicted by the sub-set of rheological variables. As expected, we find that elasticity varies in an opposite direction to the elastic modulus and to the stress at fracture, and in the same direction as the strain at fracture. Firmness varies in the same direction as the stress at fracture, but in an opposite direction with the strain at fracture and, curiously, with the elastic modulus. Deformability varies in the same direction as the strain at fracture, but also as the work to fracture, and in the opposite direction to the elastic modulus. A cheese with a higher $\mathrm{e}-$ lasticity has a lower elastic modulus, and at the same time it has a higher deformability (which is associated with a higher strain at fracture), but a lower firmness (which means here a lower stress at fracture).

The very good predictions for grainy and crystals show an indirect relation between the characteristics of texture described by rheology and the sensory attribute of texture described by grainy. The rheological measurements employed in this study were not aimed at measurements of grainy texture or crystals in Parmigiano Reggiano cheese, but considering that the grainy structure with tyrosine crystals is the result of proteolysis which affects the textural 'evolution' of this cheese during the ripening, the relation between these sensory characteristics and rheology is not a surprise. The sensory humidity, with the highest level for $R^{2}$, is very well predicted by rheological parameters. This sensory characteristic is closely correlated with the water content of Parmigiano Reggiano cheese (Zannoni et al, 1991). Results here confirmed the strong relation between moisture and mechanical aspects of texture on the sensory perception of humidity.

Among the variates poorly predicted, brittleness is not influenced by age but only by cheese, and adhesivity is neither influenced by age nor by cheese. We would have expected a good prediction of brittleness to rheology but the small amount of variation between samples relative to the sampling error may explain the poor relationship with rheology.

As expected, floury is not predicted by rheological parameters. It is not a sensory characteristic commonly used to describe texture of Parmigiano Reggiano, however, a small effect of age has been shown in this study.

\section{CONCLUSIONS}

Sensory and rheological analyses of the texture of Parmigiano Reggiano give evidence of similarity, especially in relation with age and cheese effects, even if the number of samples was limited in this preliminary study. Representation of the data as a biplot shows similar clusters of cheeses based on age. The four 28-monthold cheeses are clearly clustered, while the 18- and 12-month-old cheeses are in more widely dispersed groups, slightly intermingled.

Four rheological parameters (elastic modulus, stress and strain at fracture and work to fracture) satisfactorily describe the texture of Parmigiano Reggiano cheese. In this study, while stress and work at fracture are mainly influenced by cheese, the apparent elastic modulus and the strain at frac- 
ture are influenced by age and cheese. Cheese texture is known to be highly influenced by ripening, but milk and cheesemaking conditions, which contribute to the cheese effect, would also influence the final quality of the Parmigiano Reggiano cheese.

As expected, elasticity, deformability and firmness are well predicted by the four rheological variates, while brittleness is poorly predicted. Surprisingly, humidity is the sensory attribute predicted best and grainy and crystals also are quite well predicted by the rheological parameters. Rheological tests are expected to directly estimate mechanical textural parameters but not geometrical or surface ones. The strong correlations found support the choice to retain the non-mechanical sensory variates of texture in this relational study. Clearly, these relationships are not causative but they suggest indirect relations. Textural attributes are determined by the cheese structure and we can assume that the structural arrangements at different levels are responsible for the mechanical dimension of texture perception as well as the geometrical dimension and possibly the surface one. Thus, we have reason to believe that relations between the different dimensions of texture exist.

Rheology is more sensitive than sensory analysis to the effects of age but sensory results can estimate more textural parameters than rheology. Thus the two methods are complementary.

The statistical method used, PLS regression, establishes relationships based on linear combinations. The high levels of correlations found suggest that the linear relationships are a good basis to predict sensory textural attributes with rheology.

The relationships described in this paper show that there is an opportunity to base a quality control system for Parmigiano Reggiano cheese on rheological measurement. But further evaluation of a great number of cheeses would be needed to obtain conclusive results for this purpose.

\section{ACKNOWLEDGEMENTS}

The authors acknowledge P Schlich (INRA, Laboratoire des Aromes, France) to allow the use of a macro command developed with SAS software (SAS Institute Inc, USA) to produce publication quality figures. This work was partially supported by funds from the Institut National de la Recherche Agronomique, the Consorzio del Formaggio Parmigiano Reggiano and the Scottish Office Agriculture and Fisheries Department. The EC FLAIR Concerted Action No 2, COST 902 (SENS) provided funds for travel and for meetings between the partners.

\section{REFERENCES}

AFNOR (1992) Sensory analysis - Vocabulary. Norme NF ISO 5492.

Anonymous (1990) Rheological testing of cheese. Int Dairy Fed publication E-Doc 424

Berdagué JL, Grappin A (1988) Affinage et qualité du gruyẻre de Comtè. Caractéristiques sensorielles des fromages. Lait $68,189-204$

Bosset JO, Collomb M, Eberhard P, Grand M, Lavanchy P, Kaufmann E, Kreuter U (1992) Application de méthodes d'analyse statistique univariée et multivariée à l'étude parallèle de critères chimiques, biochimiques, rhéologiques, microbiologiques et sensoriels du fromage d'emmental au moment de sa taxation. Partie I: Analyse de quelques profils de distribution. Chimia 46, 406-415

Bosset JO, Collomb M, Eberhard P, Grand M, Lavanchy P, Kaufmann E, Kreuter U (1993a) Application de méthodes d'analyse statistique univariée et multivariée à l'étude parallèle de critères chimiques, biochimiques, rhéologiques, microbiologiques et sensoriels du fromage d'emmental au moment de sa taxation. Partie II: Analyse de corrélation. Lebensm Technol 26, 111-116

Bosset JO, Collomb M, Eberhard P, Grand M, Lavanchy P, Kaufmann E, Kreuter U (1993b) Application de méthodes d'analyse statistique univariée et multivariée à l'étude parallèle de critères chimiques, biochimiques, héologiques, microbiologiques et sensoriels du fromage d'emmental au moment de sa taxation. Partie III: Analyse de régression linéaire multiple et analyse discriminante. Lebensm Technol 26, 151-160

Brockhoff P, Skovgaard I, Poll L, Hansen K (1993) A comparison of methods for linear prediction of apple flavour from gas chromatographic measurements. Food Qual Pref 4, 215-222

Bütikofer U, Rūegg M, Ardô Y (1993) Determination of nitrogen fraction in cheese: Evaluation of a collaborative study. Lebensm Wiss Technol 26, 271-275

Cardenas-Caroti R, Grosclaude G, Nicol G, Maubois JL (1985) Rhéométre pour l'étude des produits non 
conformes en corps linéaires. Brevet FR $n^{\circ} 85$ 14870

Chen AH, Larkin JW, Clark CJ, Irwin WE (1979) Texture analysis of cheese. J Dairy Sci 62, 901-907

Grappin R, Lefier D, Dasen A, Pochet S (1993) Characterizing ripening of Gruyère de Comté: Influence of time $\times$ temperature and salting conditions on eye and slit formation. Int Dairy J3, 313-328

Hennequin D, Hardy J (1993) Evaluation intrumentale et sensorielle de certaines propriétés texturales de fromages à pâte molle. Int Dairy $J 3,635-647$

Jack FR, Piggott JR, Paterson A (1993) Relationships between electromyography, sensory and instrumental measures of Cheddar cheese texture. J Food Sci $58,1313-1317$

Krzanowski WJ (1988) Principles of Multivariate Analysis: A User's Perspective. Clarendon Press, Oxford, United Kingdom

Lavanchy P, Bérodier F, Zannoni M, Noël Y, Adamo C, Squella J, Herrero L (1993) L'évaluation sensorielle de la texture des fromages à pâte dure ou semidure. Etude inter-laboratoires. Lebensm Wiss Technol 26, 59-68

Luyten $\mathrm{H}$ (1988) The rheological and fracture properties of Gouda cheese. Ph D thesis, Wageningen Agricultural University, Wageningen, the Netherlands

Luyten $\mathrm{H}$, van Vliet T, Walstra P (1991) Characterization of the consistency of Gouda cheese: rheological properties. Neth Milk Dairy J 45, 33-53

Marshall RJ (1991) Combined instrumental and sensory measurement of the role of fat in food texture. Food Qual Pref 2, 117-124

Martens M, Martens H (1986) Partial least squares regression. In: Statistical Procedures in Food Research (Piggott JR, ed) Elsevier Applied Science, London

Molander E, Kristiansen KR, Werner H (1990) Instrumental and sensoric measurement of Brie texture. Milchwissenschaft 45, 589-593

Reiner M (1971) Advanced rheology. HK Lewis and Co Ltd, London
Rohm H, Lederer H, Ginzinger W (1992a) Relationship between rheological properties and composition of Swiss-type cheese. 1. Multiple regression analysis. Lebensm Wiss Technol 25, 253-260

Rohm H, Lederer H, Ginzinger W (1992b) Relationship between rheological properties and composition of Swiss-type cheese. 2. Principal component regression. Milchwissenschaft 47,620-623

Rüegg M (1985) Water in dairy products related to quality, with special reference to cheese. In: Properties of Water in Foods (Simatos D, Multon JL, eds). Martinus Nijhoff Publishers, Dordrecht

Szczesniak AS (1987) Correlating sensory with instrumental texture measurements - An overview of recent developments. J Texture Stud 18, 1-15

Virgili R, Parorali G, Bolzoni L, Barbieri G, Mangia A, Careri M, Spagnoli S, Panari G, Zannoni M (1994) Sensory-chemical relationships in Parmigiano Reggiano cheese. Lebensm Wiss Technol 27, 491-495

van Vliet T, Peleg M (1991) Effects of sample size and preparation. Chapter 4. In: Rheological and fracture properties of cheese. Bull Int Dairy Fed 268, 26-29

Walstra P, van Vliet T (1982) Rheology of cheese. Bull Int Dairy Fed 153, 22-27

Walstra P, Peleg M (1991) General considerations. Chap 1. In: Rheological and fracture properties of cheese. Bull Int Dairy Fed 268, 3-4

Williams AA, Rogers CA, Collins AJ (1988) Relating chemical physical and sensory data in food acceptance studies. Food Qual Pref 1, 25-31

Zannoni M, Bertozzi L, Mora R (1991) Indagine preliminare sulle caratteristiche sensoriali del ParmigianoReggiano: la struttura. Sci Tecn Latt Casearia 42, 192-202

Zoon P (1991) The relation between instrumental and sensory evaluation of the rheological and fractureproperties of cheese. Chapter 5. In: Rheological and fracture properties of cheese. Bull Int Dairy Fed268, 30-35 